Research Papers

\title{
The Influence of Body Condition on the Stopover Ecology of Least Sandpipers in the Lower Mississippi Alluvial Valley during Fall Migration
}

\section{Influence de l'état corporel sur l'écologie du Bécasseau minuscule en halte migratoire dans la vallée alluviale du Mississippi inférieur durant la migration automnale}

\author{
$\underline{\text { Sarah E. Lehnen }}^{1}$ and David G. Krementz ${ }^{1}$
}

\begin{abstract}
Many shorebirds are long-distance migrants and depend on the energy gained at stopover sites to complete migration. Competing hypotheses have described strategies used by migrating birds; the energy-selection hypothesis predicts that shorebirds attempt to maximize energy gained at stopover sites, whereas the time-selection hypothesis predicts that shorebirds attempt to minimize time spent at stopover sites. The energy- and time-selection hypotheses both predict that birds in better condition will depart sites sooner. However, numerous studies of stopover duration have found little support for this prediction, leading to the suggestion that migrating birds operate under energy and time constraints for only a small portion of the migratory season. During fall migration 2002, we tested the prediction that birds in better condition depart stopover sites sooner by examining the relationship between stopover duration and body condition for migrating Least Sandpipers (Calidris minutilla) at three stopover sites in the Lower Mississippi Alluvial Valley. We also tested the assumption made by the Lower Mississippi Alluvial Valley Migratory Bird Science Team that shorebirds stay in the Mississippi Valley for $10 \mathrm{~d}$. The assumption of $10 \mathrm{~d}$ was used to estimate the amount of habitat required by shorebirds in the Mississippi Valley during fall migration; a period longer than $10 \mathrm{~d}$ would increase the estimate of the amount habitat required. We used multiple-day constancy models of apparent survival and program MARK to estimate stopover duration for 293 individually color-marked and resighted Least Sandpipers. We found that a four-day constancy interval and a site $\mathrm{x}$ quadratic time trend interaction term best modeled apparent survival. We found only weak support for body condition as a factor explaining length of stopover duration, which is consistent with findings from similar work. Stopover duration estimates were $4.1 \mathrm{~d}(95 \% \mathrm{CI}=2.8-6.1)$ for adult Least Sandpipers at Bald Knob National Wildlife Refuge, Arkansas, 6.5 d (95\% CI $=4.9-8.7)$ for adult and 6.1 d (95\% CI $=4.2-9.1)$ for juvenile Least Sandpipers at Yazoo National Wildlife Refuge, Mississippi, and $6.9 \mathrm{~d}(95 \% \mathrm{CI}=5.5-8.7)$ for juvenile Least Sandpipers at Morgan Brake National Wildlife Refuge, Mississippi. Based on our estimates of stopover duration and the assumption made by the Lower Mississippi Alluvial Valley Migratory Bird Science Team, there is sufficient habitat in the lower Mississippi Valley to support shorebirds during fall migration.
\end{abstract}

RÉSUMÉ. De nombreux oiseaux de rivage migrent sur de longues distances et dépendent de l'énergie accumulée aux haltes migratoires pour compléter leur migration. Il existe deux hypothèses concurrentes pour définir les stratégies utilisées par les oiseaux en migration : l'hypothèse énergétique suppose que les oiseaux tentent de maximiser leurs gains énergétiques sur les haltes migratoires, tandis que l'hypothèse temporelle avance qu'ils tentent de minimiser leur durée de séjour à ces endroits. Ces hypothèses prédisent toutes deux que les oiseaux en meilleure condition vont quitter les haltes migratoires plus hâtivement que

${ }^{1}$ USGS Arkansas Cooperative Fish and Wildlife Research Unit, Department of Biological Sciences - University of Arkansas,

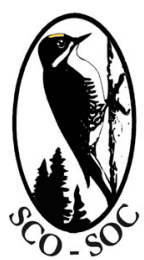

Sponsored by the Society of Canadian Ornithologists and Bird Studies Canada

Parrainée par la Société des ornithologistes du Canada et Études d'oiseaux Canada

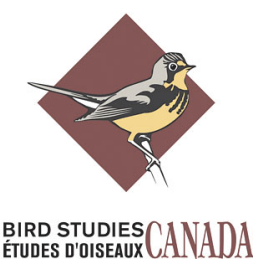


ceux en moins bonne condition. Toutefois, plusieurs études sur la durée de séjour aux haltes migratoires n'ont soutenu que faiblement cette prédiction, ce qui donne à penser que les oiseaux en migration sont soumis à des contraintes énergétiques et temporelles seulement durant une petite partie de la migration. Durant la migration automnale de 2002, nous avons testé la prédiction selon laquelle les oiseaux en meilleure condition quittent les haltes migratoires plus hâtivement en étudiant la relation entre la durée de séjour et l'état corporel de Bécasseaux minuscules (Calidris minutilla) à trois haltes migratoires dans la vallée alluviale du Mississippi inférieur. Nous avons aussi vérifié la supposition du Lower Mississippi Alluvial Valley Migratory Bird Science Team selon laquelle les oiseaux de rivage séjournent 10 jours dans la vallée du Mississippi. Cette durée présumée de séjour de 10 jours a été utilisée pour évaluer la quantité d'habitat nécessaire aux oiseaux de rivage en migration automnale dans la vallée du Mississippi; une période plus longue augmenterait la quantité d'habitat nécessaire. Nous avons utilisé des modèles de constance sur plusieurs jours de la survie apparente et le programme MARK afin d'estimer la durée de séjour de 293 Bécasseaux minuscules marqués à l'aide de bagues de couleurs et revus. Nous avons trouvé qu'un intervalle constant de quatre jours et un terme d'interaction site $\mathrm{x}$ tendance temporelle quadratique expliquaient le mieux la survie apparente. Nous avons trouvé peu d'appui à l'effet que l'état corporel puisse être une variable explicative de la durée de séjour, ce qui correspond aux résultats d'études similaires. Nous avons estimé que la durée de séjour aux haltes migratoires était de 4,1 jours (IC $95 \%=2,8-6,1$ ) pour les adultes au Bald Knob National Wildlife Refuge, en Arkansas, de 6,5 jours (IC 95 \% = 4,9-8,7) pour les adultes et de 6,1 jours (IC $95 \%=4,2-9,1$ ) pour les jeunes au Yazoo National Wildlife Refuge, au Mississippi, et de 6,9 jours (IC $95 \%=5,5-8,7$ ) pour les jeunes au Morgan Brake National Wildlife Refuge, au Mississippi. D'après ces estimations et la supposition du Lower Mississippi Alluvial Valley Migratory Bird Science Team, il y a suffisamment d'habitat dans la vallée du Mississippi inférieur pour subvenir aux besoins des oiseaux de rivage au cours de la période de migration automnale.

Key Words: Calidris minutilla; Least Sandpiper; mark-resight; migration; sandpiper; stopover duration.

\section{INTRODUCTION}

Many shorebirds make annual journeys from their high Arctic breeding grounds to their wintering areas in temperate and tropical regions (Myers et al. 1987). During migration, these birds rest and refuel at one or more stopover sites. Little is known about the length of time that shorebirds will stay at one site (Iverson et al. 1996), a parameter we refer to as stopover duration. Stopover duration has also been termed stopover, stopover length, i.e., time, period, duration of stay, length of stay, migratory pause, resting period, residency, and overlap (Kaiser 1999). Minimum length of stay or stopover length has typically been used to describe the time from first capture until last capture or resighting. Although surveys at stopover sites are often used as indices to population size, Ydenberg et al. (2004) found that decreased stopover durations over a twodecade period explained all or most of the declines in the number of shorebirds surveyed at several sites in British Columbia, making surveys alone a potentially biased method of population estimation. Bart et al. (2007) reported significant declines in the number of shorebirds observed during fall migration although the results were not consistent between regions. The authors believed population decline to be the most likely reason for the reduction in shorebird numbers but they could not rule out a change in behavior such as shorter stopover durations as an explanation. These studies illustrate the need for empirical estimates of stopover duration.

Previous studies of color-marked birds have used the median or arithmetic mean of the time from capture until the last resighting as an estimate of minimum stopover duration (Butler et al. 1987, Hicklin 1987, Lyons and Haig 1995). This method relies exclusively on birds that were resighted at least once after capture, and hence uses only a small and potentially biased amount of the available data (Kaiser 1999). In addition, nothing is known about the actual arrival or departure dates of the birds (Kaiser 1999). Some studies have addressed this problem by using Cormack-Jolly-Seber models to estimate the probability of leaving a site after capture (Holmgren et al. 1993, Kaiser 1995, 
Dinsmore and Collazo 2003), an approach we will follow. We will also use multiple-day constancy (MDC) models. Morris et al. (2005) found that data sets pooled across days or weeks typically overestimated stopover duration, whereas multipleday constancy (MDC) models in which the apparent survival probability is held constant over a period of days did not have this bias.

Two competing hypotheses attempt to predict how long birds stay at stopover sites. The energyselection hypothesis predicts shorebirds will depart a stopover site once their energy reserves are sufficient to cover the distance, regardless of the quality of the next site. An alternative, the timeselection hypothesis, predicts shorebirds will minimize the time they spend at stopover sites and bypass poor quality sites in order to reduce the total time spent migrating. Because fall migrants are not under as tight time constraints as spring migrants, Lyons and Haig (1995) suggested they operate under the energy-selection hypothesis, whereas spring migrants operate under the time-selection hypothesis. Under both hypotheses, birds in better condition should have shorter stopover durations. However, the majority of empirical studies have found little evidence supporting the conditionstopover duration relationship (Gudmunsson et al. 1991, Holgren et al. 1993, Skagen and Knopf 1994, Lyons and Haig 1995, Warnock and Bishop 1998, Pfister et al. 1998, Dinsmore and Collazo 2003, Warnock et al. 2004). Other researchers have suggested that predation risk (Ydenberg et al. 2004) and wind (Butler et al. 1997; but see Weber et al. 1998) strongly influence stopover duration. Given the multitude of pressures birds operate under during migration, it may be that no single explanation can adequately describe migratory strategy.

Estimates of stopover duration are also needed to calculate turnover rate in the Mississippi Alluvial Valley (Mississippi Valley), where turnover rate is the average number of days that it takes a bird to pass through the Mississippi Valley. Turnover rate and stopover duration are equivalent when shorebirds use only one stopover site within the Mississippi Valley during fall migration. Otherwise, turnover rate is estimated by average stopover duration multiplied by the number of sites used. The Lower Mississippi Valley Joint Venture Migratory Bird Science Team developed management objectives based on the assumption that the average turnover rate for a shorebird traveling through the region during fall migration was $10 \mathrm{~d}$ (Loesch et al. 2000). However, due to the lack of research in this region, this number was the best guess of shorebird experts and was not based on empirical data. Because of this lack of empirical data, estimating the turnover rate of fall migrating shorebirds is one of the top research priorities for those studying shorebirds in the Mississippi Valley (Loesch et al. 2000). Assuming that estimates of shorebird numbers and energetic requirements used by the Migratory Bird Science Team remain the same, a turnover rate longer than $10 \mathrm{~d}$ would increase the estimate of the amount of habitat required by shorebirds in the Mississippi Valley during fall migration.

Our aim was to estimate stopover durations of colormarked Least Sandpipers (Calidris minutilla) in the lower Mississippi Valley in order to test the prediction that birds in better condition will depart sites sooner. In addition, we wanted to test the assumption that shorebirds stay in the Mississippi Valley for $10 \mathrm{~d}$ in order to better manage shorebird habitat in the region. We chose the Least Sandpiper as our study species because it is abundant at shorebird stopover sites in the interior of North America throughout fall migration (James and Neal 1986, Cooper 1994). In addition, the Least Sandpiper is a typical interior shorebird migrant in that it freely intermingles with small congeners and is thus a good species for inferring overall shorebird migration patterns for interior North America.

\section{METHODS}

\section{Study area}

We studied migrating Least Sandpipers at three sites in the Mississippi Alluvial Valley: Bald Knob National Wildlife Refuge (Bald Knob) in Arkansas, and Yazoo and Morgan Brake National Wildlife Refuges in Mississippi (Yazoo and Morgan Brake, respectively; Fig. 1). Bald Knob was a 5920-ha refuge located in White County in eastern Arkansas. Shorebird habitat at Bald Knob consisted of a single 32-ha impoundment that was slowly drawn down to expose mudflats attractive to foraging shorebirds. Yazoo was a 5237-ha refuge located in Washington County, in western Mississippi, $6 \mathrm{~km}$ east of the Mississippi River. The 14 former catfish ponds at Yazoo were managed for shorebirds and waterfowl on a 4-yr rotational basis. During 2002, 4 of the 14 impoundments were flooded and drawn down to 
attract migrating shorebirds. The impoundments ranged in size from 3-8 ha. Morgan Brake was a 2987-ha refuge located in Holmes County in westcentral Mississippi. Six impoundments ranging in size from 5-8 ha were managed for shorebirds via drawdown.

\section{Mist-netting}

We used $10,12 \times 2.6 \mathrm{~m}$ (30 mm mesh) mist nets to capture Least Sandpipers. Nets were grouped in " $T$ " and "L" shapes at the water's edge. We opened the nets 15 min before sunrise and closed the nets when temperatures exceeded $28^{\circ}$ or wind exceeded 34 $\mathrm{kph}$, which usually occurred between 1000-1100 CST. Shorebirds were captured as they flew into the nets on their own or flushed into the nets by $>2$ people walking toward the birds as they fed. We banded birds at Bald Knob from 26 July to 23 August, at Yazoo from 14 August to 5 September, and at Morgan Brake from 8 to 24 September during 2002.

We placed a federal numbered aluminum band on the upper leg of each Least Sandpiper and recorded culmen and wing chord lengths ( $\mathrm{mm}$ ) and body mass (g). We also used permanent green, red, and yellow markers to mark the breast of each bird with a unique color pattern. Culmen length was used to sex Least Sandpipers (Prater et al. 1977), resulting in $78 \%$ of the birds classified as female. Using this same method, Butler and Kaiser (1995) classified 63\% ( $=1280$ ) of their captured Least Sandpipers as females. They concluded that the accuracy of sexing Least Sandpipers using culmen lengths needed reexamination. We agree that the high percentage of females classified by the method is suspect so we did not include sex as a variable. All birds were aged as being either juvenile, i.e., hatch-year, or adult, $i$. e., after hatch-year, birds according to the shape, brightness, and condition of the flight feathers, and the color of the breast (Prater et al. 1977). After all measurements were recorded, we released each bird at the capture site within 45 min of capture.

At each site and for 2-3 h every afternoon, we surveyed all potential shorebird habitat at the site to relocate marked birds. Each Least Sandpiper located was checked for a color mark. Resighting continued for a week following the end of banding at each site. The Institutional Animal Care and Use Committee at the University of Arkansas approved this protocol (\#01025).

\section{Condition index}

We calculated a condition index using an ordinary least squares (OLS) linear regression of body mass against wing chord length and then used the residual of mass as the condition index for that bird. Use of residuals assumed that (1) mass increased linearly with wing length, (2) the proportion of body mass made of energy stores was independent of wing length (Green 2001), and (3) variation in residual body mass was determined by variation in fat and protein reserves. Due to possible variation in residual body mass by age, we used analysis of covariance to test for the effect of age on residual body mass. If the effect of age was significant, we then used separate linear regressions to determine condition indices for adults and juveniles.

\section{Statistical analyses}

We used multiple-day-constancy (MDC) models. We could not use fully time-dependent models because of the relatively small sample size with respect to the number of days in the study. Pooling the data over a period of days or weeks reduces the number of parameters that need to be estimated in time-dependent models but has been shown to overestimate stopover duration (Morris et al. 2005) and also results in a loss of information during the pooled period. MDC models hold parameters constant for multiple days, reducing the number of parameters as with pooling but without the bias and loss of information. Because our ability to sex Least Sandpipers was limited, we pooled our data across sexes.

We ran the mark-resight data through models that estimated apparent survival (phi; $\phi)$. Apparent survival is defined as $\phi=\mathrm{S} * F$ where $\mathrm{S}$ is true survival and $F$ is the probability of remaining at that site or site fidelity (Sandercock 2006). Cooper (1993) observed a return rate of $91 \%(n=68)$ based on birds originally banded as chicks and recaptured on the breeding site the following year. Assuming a constant rate, this would translate to a minimum monthly survival rate of 0.99 . Given this high survival rate and considering the short duration of this study we assumed that the true survival rate of Least Sandpipers at our sites was close to 1, making $\phi$ the probability of a bird remaining at the site. Because we had no reason to believe that true survival rates varied by site, we interpreted $\phi_{i}$ as the probability that a bird at the site at time $i$ remained at the site at time $i+1$. Resighting probability $\left(P_{i}\right)$ 
Fig. 1. Study sites in the Lower Mississippi Alluvial Valley during fall 2002.

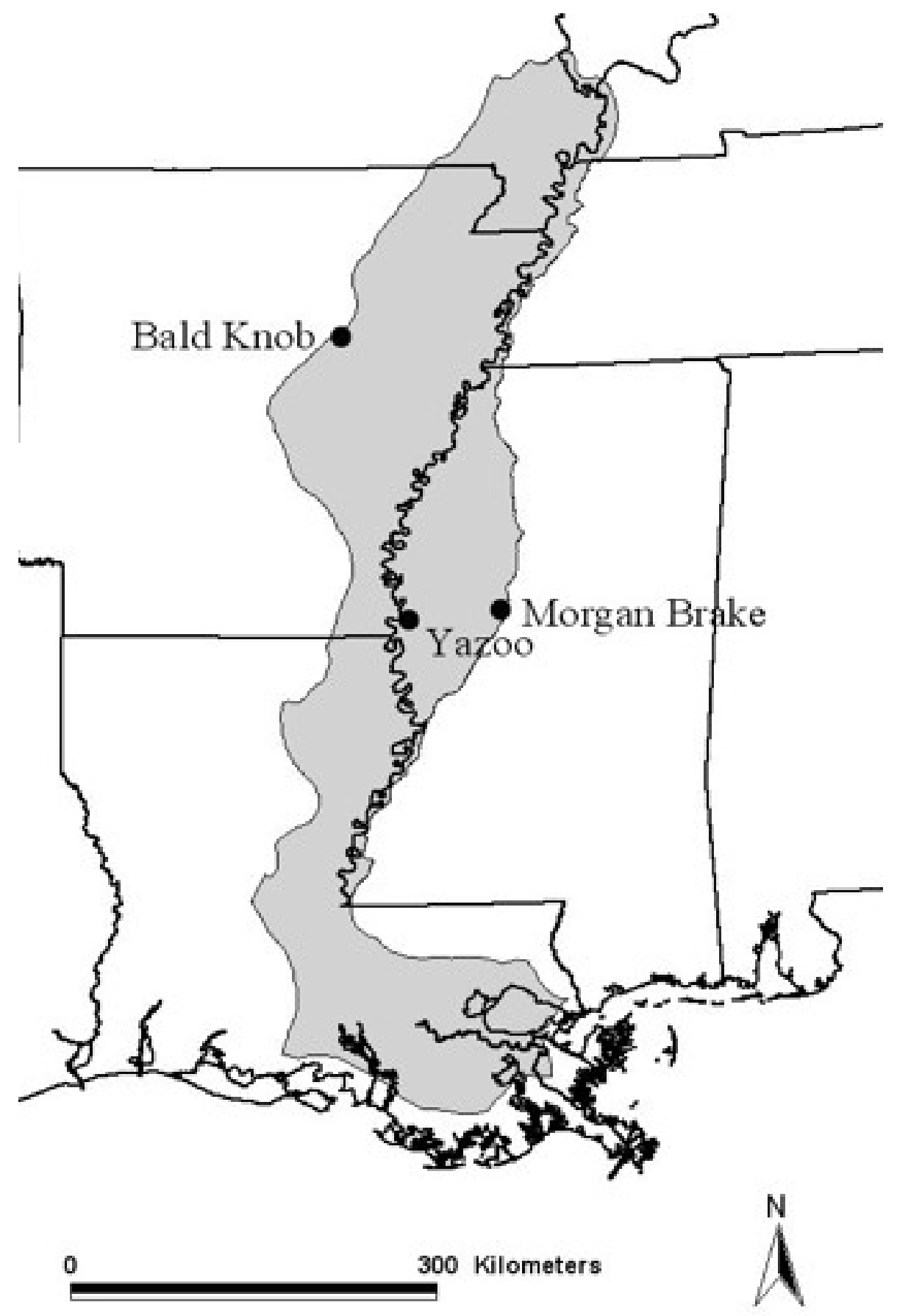


was the probability that a bird at a site at time $i$ was seen at time $i$, assuming that emigration was permanent.

\section{Estimation of stopover duration}

Stopover duration was estimated using the equation duration $=1 / \ln (\phi)$ (Burnham et al. 1987). In order to estimate stopover duration, we had to make a number of assumptions that may have inadvertently introduced bias into our estimates. We assumed that color combinations were read correctly and that the colors did not fade while the birds remained at the site. Because we chose colors that were distinct from each other and that remained visible for at least 3 wk, we feel that making these assumptions was both necessary and valid. We also assumed that the color marking did not increase depredation of marked Least Sandpipers, which we justify by the short duration of the study. Although falcons and other potential predators were occasionally observed in the study areas, during the year of this study and the previous year no successful strikes were observed, nor did the attempted strikes appear to target colormarked individuals.

\section{Model selection and building}

We used program MARK (White and Burnham 1999) and the CJS/recaptures only model to estimate $\phi$ and $P$ following the informationtheoretic approach (Burnham and Anderson 2002). When building models, we used two link functions; models incorporating condition index as a covariate used the logit link function, all other models used the sin link function. Both the sin and logit link functions constrain the real parameters in the $[0,1]$ interval, but the sin function performs better when the estimate is close to the boundary of 0 or 1 . The logit link function is used for non-identity design matrices including models using covariates. We assessed the fit of the global model using the median c-hat procedure implemented in program MARK (Cooch and White 2004). We then selected models using Akaike's information criteria (AIC; Akaike 1973) adjusted for quasi-likelihood and small sample size (QAIC ; Burnham and Anderson 2002).

The global model of a candidate set is the model that contains all the effects that the researcher believes to be reasonable. In our global model, we included the effect of site-age, time, and the interaction between the two terms in our estimates of $\phi$, and the effect of site on $P$. Because of confounding between age and site, we split the Least Sandpipers into four site-age groups: Bald Knob adults, Yazoo adults, Yazoo juveniles, and Morgan Brake juveniles in order to tests for effects. Due to differential migration, no juveniles were captured at Bald Knob and no adults were captured at Morgan Brake resulting in four site-age groups rather than six. We used a "." in the encounter history to indicate an occasion when a site was not surveyed (White and Burnham 1999). Site-age and time effects were included in the $\phi$ parameters to account for differences in habitat and food availability among sites, differences due to age, and to accommodate for temporal changes in the amount and quality of habitat within a site. In addition, strategies of early and late migrants may have differed causing stopover duration to vary over time. We included a site effect in capture probability because, although resighting effort among the sites was constant, sites differed in the size of the impoundments and the amount of vegetation and other viewing obstructions present and we anticipated that these differences would affect resighting probabilities. To select an optimal multiple-day period, we ran multiple-day intervals of $1,2,4,6$, and $8 \mathrm{~d}$. Using the best constancy interval, we then ran time as both a linear and quadratic trend to test if these models performed better than the time independent model. Finally, to the best of these models, we added the covariate residual condition index to test for the effect of condition on stopover duration. Condition index was added as an effect for all birds and then for adult and juvenile birds separately.

\section{RESULTS}

\section{Mist-netting}

We individually marked 293 Least Sandpipers during 2002: 50 at Bald Knob, 135 at Yazoo, and 108 at Morgan Brake (Table 1). Capture effort differed by site; we banded for 636 net hrs at Bald Knob, 504 net hours at Yazoo, and 384 net hrs at Morgan Brake. Birds caught early in fall migration were predominantly adults, whereas birds caught during late migration were predominantly juveniles. Because of this pattern, all of the birds banded at Bald Knob, where we captured birds early in the season, were adults, whereas all of the birds banded at Morgan Brake where we captured birds late in the season were juveniles. Both adults and juveniles 
were banded at Yazoo. Residual body condition differed by age $\left(F^{1,292}=6.31, P=0.013\right)$ so we used separate linear regressions to determine condition indices for adults and juveniles.

\section{Resightings}

We resighted 293 uniquely color marked-birds over 56 encounter occasions. We had a mean of $1.1 \pm 1.4$ (SE) resightings/bird at Bald Knob, $1.7 \pm 1.9$ resightings/bird at Yazoo, and 3.2 \pm 2.1 resightings/ bird at Morgan Brake. Resighting probability $(P)$ differed by site; at Bald Knob $P=0.26(95 \% \mathrm{CI}=$ $0.18-0.36)$, at Yazoo $P=0.27(95 \% \mathrm{CI}=0.23-$ 0.32 ), and at Morgan Brake $P=0.51(95 \% \mathrm{CI}=$ $0.46-0.56)$.

\section{Model selection}

The global model adequately fit the data according to the median c-hat procedure and estimated a c-hat of 0.956 (SE 0.041) so we used the default c-hat of 1.00. We used a MDC interval of $4 \mathrm{~d}$ for the apparent survival based on model rankings (Table 2). The quadratic time trend model received the most support. For apparent survival, the top model included site-age as an effect for $\phi$ (Table 2). Because of this effect, we estimated stopover duration by examining each site-age class separately. Although models containing condition index did have some support (28 and $11 \%$ of model weights) the delta deviance of the best model was only 0.94 . In addition, the slope coefficients for these effects did not differ significantly from zero (condition index-adults $=-0.034(95 \% \mathrm{CI}-0.118$ to $0.051)$, condition index-all birds $=-0.018(95 \% \mathrm{CI}$ -0.074 to 0.038 ), condition index-juveniles $=-0.006$ (95\% CI -0.076 to 0.065$)$.

\section{Stopover duration}

Apparent survival estimates differed among sites and within season (Fig. 2). We found some evidence that adults at Bald Knob had longer stopover durations than adults at Yazoo and also that juveniles at Morgan Brake had longer average stopover durations than juveniles at Yazoo during the 4-d periods when the estimates could be made for both sites (Fig. 2). To obtain an overall estimate of the stopover duration for each site, we assumed that $\phi$ was constant within a site. Stopover duration estimates were $4.1 \mathrm{~d}(95 \% \mathrm{CI}=2.8-6.1)$ for adult Least Sandpipers at Bald Knob National Wildlife Refuge, Arkansas, $6.5 \mathrm{~d}(95 \% \mathrm{CI}=4.9-8.7)$ for adult and 6.1 (95\% CI $=4.2-9.1)$ for juvenile Least Sandpipers at Yazoo National Wildlife Refuge, Mississippi, and $6.9 \mathrm{~d}$ (95\% CI $=5.5-8.7)$ for juvenile Least Sandpipers at Morgan Brake National Wildlife Refuge, Mississippi.

For comparison to other methods and other studies, we also estimated length of stay using traditional methods (Table 3). Earlier methods of estimating stopover duration include use of the mean time between capture and the last resighting and/or recapture. Studies using this method have included estimates using all birds or only birds observed at least once after capture. Excluding birds never resighted was an attempt to exclude transients from the estimates of stopover duration. Additional studies have estimated stopover duration using radio-marked birds at stopover sites. Our estimates of stopover duration are within the range of estimates of previous studies. In our study, use of mean time between capture and the last resighting tended to underestimate stopover duration when all birds were included and tended to overestimate stopover duration when only birds resighted at least once were included. This relationship varied by site due to the differing resighting probabilities among sites.

\section{DISCUSSION}

Although there was some support for models containing condition index, condition failed to significantly explain stopover duration as predicted by both the time- and energy-selection hypotheses. There may have been violations in our assumptions of the relationship between wing chord length and body mass that made our condition index a poor predictor of fat stores. Modeling stopover duration using condition indices assumes that birds in different condition have the same fat deposition rate, a claim that is largely untested (Green 2001). We also did not account for the effect of weather on influencing site departure (Butler et al. 1997). Plasma metabolites can predict fat deposition rates in the days following capture and thus may be better suited for modeling stopover durations (Dinsmore and Collazo 2003). In future studies, the use of 
Table 1. Least Sandpipers captured by sex and age at Bald Knob National Wildlife Refuge (Bald Knob) in Arkansas, and Yazoo National Wildlife Refuge (Yazoo), and Morgan Brake National Wildlife Refuge (Morgan Brake) in Mississippi during July-September 2002.

\begin{tabular}{lccccccc}
\hline \hline Site & Banding Dates & Male & $\begin{array}{c}\text { Adult } \\
\text { Female }\end{array}$ & Uk & Male & Juvenile & Uk \\
& & & & & Female \\
\hline Bald Knob & 26 Jul.-23 Aug. & 7 & 34 & 9 & 0 & 0 & 0 \\
Yazoo & 14 Aug.-5 Sept. & 10 & 47 & 23 & 8 & 24 & 23 \\
Morgan Brake & 8 Sept.-24 Sept & 0 & 0 & 0 & 23 & 60 & 35
\end{tabular}

plasma metablolites combined with body condition may better predict individual stopover duration.

The strategies that fall migrating shorebirds use to decide how long to stay at a particular stopover site are thought to include time, energy, and predation risk (Alerstam and Lindstrom 1990, Gudmundsson et al. 1991, but see Butler et al. 1997). Although the hypotheses behind the decision process to remain or leave a particular site were developed for longdistance spring migrating shorebirds, the validity of those decision-making steps should hold true for fall migrating shorebirds (Gudmundsson et al. 1991). In the spring, some long-distance migrating shorebirds exhibit fat store overloading and bypassing possible staging areas in an attempt to maximize the overall speed of migration. The evidence for fall migrating shorebirds suggests that such strategies are relaxed and so migrants tend not to overload fat reserves and too, they do not always by-pass stopover sites (Gudmundsson et al. 1991). Thus, it would seem that fall migrating shorebirds should not overload fat reserves, visit more stopover sites, and take longer to migrate as compared to their spring migration patterns.

Based on banding data, we found that adult and juvenile Least Sandpipers migrated in two distinct peaks during fall 2002. We anticipated this pattern based on previous research on migration chronology of Least Sandpipers (Cooper 1994). However we note that juveniles are known to be captured more frequently than adults (Pienkowski and Dick 1976, Goss-Custard et al. 1981), so the proportion of birds banded in each age class was not necessarily representative of the age distribution of birds present.

Across our three sites, we found some evidence that adults at Bald Knob had longer stopover durations than adults at Yazoo and also that juveniles at Morgan Brake had longer average stopover durations than juveniles at Yazoo during the 4-day periods when the estimates could be made for both sites (Fig. 2). The longer stay at Morgan Brake probably did not result from a latitudinal difference as the sites were $<80 \mathrm{~km}$ apart, but may have resulted from differences in the habitat quality at the sites. Invertebrate abundance is thought to be more important than species composition in shorebird management (Skagen and Oman 1996); and so invertebrate density may be a good measure of habitat quality. Based on Mitchell and Grubaugh (2005), the invertebrate density during the fall migratory period of 2002 was similar at Bald Knob $\left(3.30 \mathrm{~g} / \mathrm{m}^{2}\right)$ and Morgan Brake $\left(3.22 \mathrm{~g} / \mathrm{m}^{2}\right)$, but more than twice as great at Yazoo $\left(7.26 \mathrm{~g} / \mathrm{m}^{2}\right)$. These differences suggest that Least Sandpipers at Morgan Brake had to forage for a longer period than birds at Yazoo before reaching a level of energy that would allow them to migrate onward. That stopover durations at Bald Knob and Morgan Brake were different may have been due to differences in season (early vs. late), age (adult vs. juvenile), or availability of habitat near the respective sites. Note, though, that Mitchell and Grubaugh (2005) reported that shorebirds did not impact their food resources at any site suggesting that food was not a limiting 
Table 2. Model selection results for apparent survival for 293 fall-migrating Least Sandpipers in the Lower Mississippi River Alluvial Valley during Fall 2002. Models were ranked by ascending $\Delta$ AICc. Time is represented by $\mathrm{t}$ followed by the constancy interval. The terms ciad, ci, and cijv represent condition index of adults, condition index of all birds, and condition index of juveniles, respectively. T and TT represent linear and quadratic time trends, respectively.

\begin{tabular}{|c|c|c|c|c|}
\hline Model & $\mathrm{K}$ & Deviance & $\Delta \mathrm{AICc} *$ & wi \\
\hline$\phi(\mathrm{TT} 4 *$ group $) \mathrm{p}($ site $)$ & 15 & 2154.11 & 0.00 & 0.46 \\
\hline$\phi(\mathrm{TT} 4 *$ group + ci) p(site) & 16 & 2152.97 & 0.94 & 0.28 \\
\hline$\phi($ TT4* group+ cijv + ciad $) p($ site $)$ & 17 & 2152.77 & 2.83 & 0.11 \\
\hline$\phi(\mathrm{t} 4 *$ group $) \mathrm{p}($ site $)$ & 27 & 2132.26 & 3.52 & 0.08 \\
\hline$\phi(t 8 *$ group $) \mathrm{p}($ site $)$ & 17 & 2153.99 & 4.06 & 0.06 \\
\hline$\phi\left(t 6^{*}\right.$ group $) \mathrm{p}($ site $)$ & 21 & 2149.39 & 7.86 & 0.01 \\
\hline$\phi\left(\mathrm{T} 4 *^{*}\right.$ group $) \mathrm{p}($ site $)$ & 11 & 2177.28 & 14.89 & 0.00 \\
\hline$\phi(\mathrm{t} 2 *$ group $) \mathrm{p}($ site $)$ & 51 & 2224.34 & 39.61 & 0.00 \\
\hline$\phi($ null $) \mathrm{p}($ site $)$ & 4 & 2274.03 & 97.35 & 0.00 \\
\hline$\phi($ group $) \mathrm{p}($ site $)$ & 7 & 2269.37 & 98.78 & 0.00 \\
\hline$\phi(t 1 *$ group $) \mathrm{p}($ site $)$ & 95 & 2098.41 & 130.08 & 0.00 \\
\hline$\phi$ (group) p(null) & 5 & 2326.72 & 152.06 & 0.00 \\
\hline$\phi($ null $) \mathrm{p}($ null $)$ & 2 & 2345.52 & 164.80 & 0.00 \\
\hline
\end{tabular}

resource. Prey depletion by Western Sandpipers $(C$. mauri) was not thought to influence length of stay along the Pacific Coast during spring migration (Warnock and Bishop 1998).

Our estimates of stopover duration range from 4-7 d. Lack of information on shorebird migration timing and habitat use in the Mississippi Valley has hampered the development of shorebird management objectives (Loesch et al. 2000). Accurate estimates of biological parameters are needed to understand the habitat needs and to monitor changes of shorebirds numbers in the region. The LMVJV Migratory Bird Science Team developed management objectives based on the assumption that the average turnover rate for a shorebird traveling through the Mississippi Valley during fall migration was $10 \mathrm{~d}$, but this estimate was based on expert opinion rather than empirical data. However, if Least Sandpipers use multiple sites in the Mississippi Valley during their southward migration their turnover rate in the region will be longer the stopover duration. Anecdotally, a few color-marked Least Sandpipers from our sites were resighted at other sites within the Mississippi Valley. In addition, based on data collected on radiomarked Pectoral Sandpipers (Caladris melanotos) during fall 2002, many Pectoral Sandpipers used more than one stopover site during migration through the Mississippi Valley (Lehnen and Krementz 2005). Conversely, Warnock and Bishop (1998) found that radio-marked Western Sandpipers 
Fig. 2. Estimated apparent survival rate and $95 \%$ confidence intervals for Least Sandpipers at study sites in the Lower Mississippi River Alluvial Valley during fall migration 2002 derived from the model $\phi$ TT4*group p site. Triangles represent birds at Bald Knob National Wildlife Refuge, Arkansas, squares represent adult birds and circles represent juvenile birds at Yazoo National Wildlife Refuge, Mississippi, and diamonds represent birds at Morgan Brake National Wildlife Refuge, Mississippi.

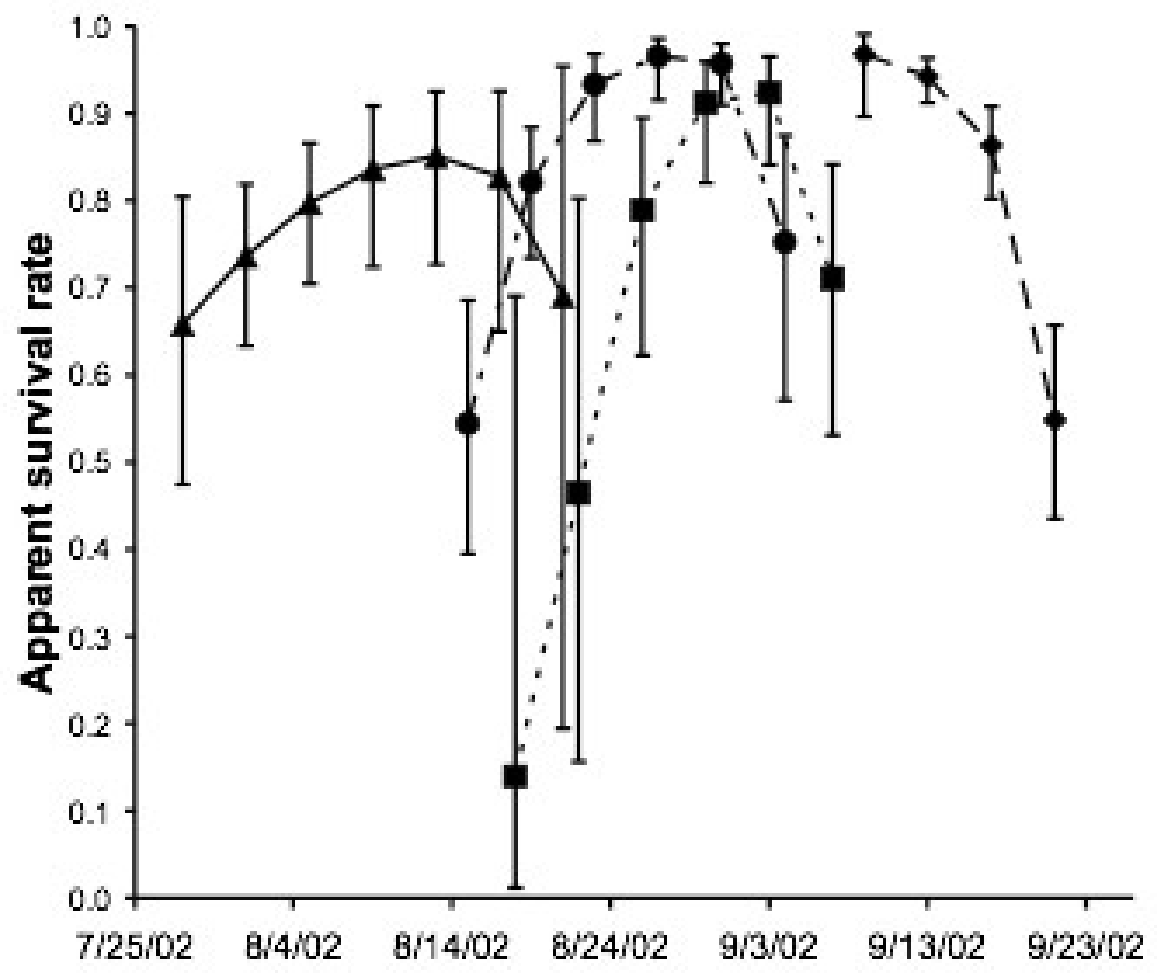

during spring migration stayed $\sim 5 \mathrm{~d}$ longer at the site of capture than birds at the same site radiomarked further south. The authors speculated that the stress of capture and/or radio-marking resulted in a temporary adjustment period of several days (Warnock and Bishop 1998, N. Warnock, PRBO Conservation Science, personal communication). However, another spring migration study on Western Sandpipers did not find evidence of handling stress (Butler et al. 2002). Assuming that (1) handling stress accounted for one day of the observed 4-7 d stopover duration, and (2) most Least Sandpipers use two stopover sites within the Mississippi Valley, our estimate of turnover rate for Least Sandpipers within the Mississippi Valley is 6-12 d.
Stopover duration estimates can be combined with shorebird counts to assess the total number of birds using a site (Frederiksen et al. 2001). Fall count data from stopover sites can be combined with stopover duration estimates to estimate bird-use days during fall migration in the Mississippi Valley, fulfilling the second research objective of the LMVJV Migratory Bird Science Team. A bird-use day is one bird that uses habitat within the Mississippi Valley for one day. Bird-use days can indicate areas of conservation importance, habitat preferences, and changes in shorebird numbers. They can also be used to estimate the amount of habitat needed by shorebirds during fall migration. Knowledge of the number of birds using a stopover site can be used as a measure of the importance of the site relative to other sites in the area (Thompson 1993). 
Table 3. Stopover duration estimates for Least Sandpipers in this study and comparison of estimates for other Calidris species.

\begin{tabular}{|c|c|c|c|c|c|c|c|}
\hline Study & Season & Species & $\begin{array}{c}\text { Type (I } \\
=\text { Interi- } \\
\text { or, } \mathrm{C}= \\
\text { Coastal) }\end{array}$ & $\begin{array}{l}\text { Estimation } \\
\text { method }\end{array}$ & $\begin{array}{l}\text { Stopover du- } \\
\text { ration (days) }\end{array}$ & $\begin{array}{l}\text { Minimum L- } \\
\text { ength of Stay } \\
\text { - all data }\end{array}$ & $\begin{array}{l}\text { Minimum Length } \\
\text { of Stay - using } \\
\text { only birds } \\
\text { resighted at least } \\
\text { once }\end{array}$ \\
\hline $\begin{array}{l}\text { This study - Bald } \\
\text { Knob }\end{array}$ & Fall & $\begin{array}{l}\text { Least Sandpiper } \\
\text { adults }\end{array}$ & I & CJS & $3.7(2.6-5.2)$ & $1.8(n=49)$ & $5.1(n=18)$ \\
\hline This study - Yazoo & Fall & $\begin{array}{l}\text { Least Sandpiper } \\
\text { adults and } \\
\text { juveniles }\end{array}$ & I & CJS & $5.1(4.2-6.1)$ & $3.7(n=135)$ & $8.0(n=62)$ \\
\hline $\begin{array}{l}\text { This study - Morgan } \\
\text { Brake }\end{array}$ & Fall & $\begin{array}{l}\text { Least Sandpiper } \\
\text { juveniles }\end{array}$ & I & CJS & $6.9(5.5-8.7)$ & $4.9(n=113)$ & $6.1(n=92)$ \\
\hline $\begin{array}{l}\text { Butler and Kaiser } \\
1995\end{array}$ & Fall & Least Sandpiper & $\mathrm{C}$ & $\begin{array}{l}\text { Maximum } \\
\text { likelihood } \\
\text { estimator }\end{array}$ & $5.0(4.3-5.9)$ & & \\
\hline Dunn et al. 1988 & Fall & $\begin{array}{l}\text { Semipalmated San- } \\
\text { dpiper } \\
\text { (C. pusilla) }\end{array}$ & $\mathrm{C}$ & & & $11.8-21.5$ & \\
\hline $\begin{array}{l}\text { Farmer and Wiens } \\
1999\end{array}$ & Spring & Pectoral Sandpiper & I & $\begin{array}{l}\text { Radio-tele- } \\
\text { metry }\end{array}$ & $8.5(5.7-11.2)$ & & \\
\hline $\begin{array}{l}\text { Farmer and Durbian } \\
2006\end{array}$ & Fall & $\begin{array}{l}\text { Pectoral and Least } \\
\text { Sandpipers }\end{array}$ & I & & $3.7(3.1-5.1)$ & & \\
\hline Iverson et al. 1996 & Spring & Western Sandpiper & $\mathrm{C}$ & $\begin{array}{l}\text { Radio-tele- } \\
\text { metry }\end{array}$ & $1-3.8$ & & \\
\hline $\begin{array}{l}\text { Lehnen and Krementz } \\
2005\end{array}$ & Fall & Pectoral Sandpiper & I & $\begin{array}{l}\text { Radio-tele- } \\
\text { metry }\end{array}$ & $10.0(8.2-11.7)$ & & \\
\hline $\begin{array}{l}\text { Skagen and Knopf } \\
1994\end{array}$ & Spring & $\begin{array}{c}\text { Semipalmated San- } \\
\text { dpiper }\end{array}$ & I & $\begin{array}{l}\text { Radio-tele- } \\
\text { metry }\end{array}$ & $7 \pm .7$ & & \\
\hline Thomas $^{1}$ & Fall & Least Sandpiper & I & $\begin{array}{l}\text { Radio-tele- } \\
\text { metry }\end{array}$ & $17-19$ & & \\
\hline Thomas 1987 & Spring & Least Sandpiper & I & & & & 11.28 .4 \\
\hline 1 Unpublished data & & & & & & & \\
\hline
\end{tabular}




\section{CONCLUSION}

We found little support for our prediction that birds in better body condition departed stopover sites sooner. Our results are consistent with that of similar studies and suggest that migratory strategies are more complicated than the time- and energyselection hypotheses. Based on our estimates of a stopover duration of 4-7 d and a turnover rate of 6$12 \mathrm{~d}$, there is sufficient habitat in the lower Mississippi Valley to support shorebirds during fall migration.

Responses to this article can be read online at:

http://www.ace-eco.org/vol2/iss2/art9/responses/

\section{Acknowledgments:}

We are especially grateful to B. Alexander at Bald Knob National Wildlife Refuge, T. Wilkens and D. Linden at Yazoo National Wildlife Refuge, and T. Carpenter and staff at Morgan Brake National Wildlife Refuge for the assistance they provided. We thank R. Wilson at the Mississippi Alluvial Valley Joint Venture for the assistance he provided. We also thank our field technicians, A. Brumec, N. Bolhman, and $V$. Genovese. This project was made possible through funding from the U. S. Fish and Wildlife Service, the Arkansas Game and Fish Commission, the USGS Arkansas Cooperative Fish and Wildlife Research Unit, the USGS Mississippi Cooperative Fish and Wildlife Research Unit, and Ducks Unlimited. We thank S. Morris and D. Sheets for advice on the analysis and B. K. Sandercock, S. J. Dinsmore, F. Sanders, and anonymous reviewers for providing comments on an earlier version of the manuscript.

\section{LITERATURE CITED}

Akaike, H. 1973. Information theory and an extension of the maximum likelihood principle. Pages 267-281 in B. N. Petran and F. Csaki, editors. International symposium on information theory. Second edition. Akad éiai Kiad ó Budapest, Hungary.

Alerstam, T., and Å Lindström. 1990. Optimal bird migration: the relative importance of time, energy, and safety. Pages 331-351 in E. Gwinner, editor. Bird migration: physiology and ecophysiology. Springer-Verlag, Berlin, Germany.

Bart, J., S. Brown, B. Harrington, and R. I. Guy Morrison. 2007. Survey trends of North American shorebirds: population declines or shifting distributions? Journal of Avian Biology 38:73-82.

Burnham, K.P., and D. R. Anderson. 2002. Model selection and multimodel inference: a practical information-theoretic approach. Springer-Verlag, New York, New York, USA.

Burnham, K. P., D. R. Anderson, G. C. White, C. Brownie, and K. H. Pollock. 1987. Design and analysis methods for fish survival experiments based on release-recapture. American Fisheries Society Monograph 5. American Fisheries Society, Bethesda, Maryland, USA.

Butler, R. W., G. W. Kaiser, and G. E. J. Smith. 1987. Migration chronology, length of stay, sex ratio, and weight of Western Sandpipers, (Calidris mauri) on the south coast of British Columbia, Canada. Journal of Field Ornithology 58:103-111.

Butler, R. W., and G. W. Kaiser. 1995. Migration chronology, sex ratio, and body mass of Least Sandpipers in British Columbia. Wilson Bulletin 107:413-422.

Butler, R. W., T. D. Williams, N. Warnock, and M.A. Bishop. 1997. Wind assistance: a requirement for migration of shorebirds? Auk 114:456-466.

Butler, R. W., P. C. F. Shepherd, and M. J. F. Lemon. 2002. Site fidelity and local movements of migrating Western Sandpipers on the Fraser River Estuary. Wilson Bulletin 114:485-490.

Cooch, E., and G. White. 2004. Using MARK: a gentle introduction. Available online at: http://www .phidot.org/software/mark/docs/book/.

Cooper, J. M. 1993. Breeding biology of the Least Sandpiper (Calidris minutilla) on the Queen Charlotte Islands, British Columbia. Thesis, University of Victoria, Victoria, British Columbia, Canada.

Cooper, J. M. 1994. Least Sandpiper (Calidris minutilla). In A. Poole and F. Gill, editors. Birds of North America, Number 115. Academy of Natural 
Sciences, Philadelphia, Pennsylvania, USA, and American Ornithologists' Union, Washington, D. C., USA.

Dinsmore, S. J., and J. A. Collazo. 2003. The influence of body condition on local apparent survival of spring migrant Sanderlings in coastal North Carolina. Condor 105:465-473.

Dunn, P. O., T. A. May, and M. A. McCollough. 1988. Length of stay and fat content of migrant Semipalmated Sandpipers in eastern Maine. Condor 90:824-835.

Farmer, A. H., and J. A. Wiens. 1999. Models and reality: time-energy trade-offs in Pectoral Sandpiper (Calidris melanotos) migration. Ecology 80:2566-2580.

Farmer, A. H., and F. Durbian. 2006. Estimating shorebird numbers at migration stopover sites. Condor 108:792-807.

Frederiksen, M., A. D. Fox, J. Madsen, and K. Colhoun. 2001. Estimating the total number of birds using a staging site. Journal of Wildlife Management 65:282-289.

Green, A. J. 2001. Mass/length residuals: measures of body condition or generators of spurious results? Ecology 82:1473-1483.

Goss-Custard, J. D., S. E. A. le V. dit Durell, H. Sitters, and R. Swinfen. 1981. Mist nets catch more juvenile oystercatchers than adults. Wader Study Group Bulletin 32:13.

Gunmundsson, G. A., ̊̊Lindströ, and T. Alerstam. 1991. Optimal fat loads and longdistance flights by migrating Knots Calidris cantus, Sanderlings, Calidris alba and Turnstones Arenaria interores. Ibis 133:140-152.

Hicklin, P. W. 1987. The migration of shorebirds in the Bay of Fundy. Wilson Bulletin 99:540-570.

Holmgren, N., H. Ellegren, and J. Pettersson. 1993. Stopover length, body mass and fuel deposition rate in autumn migrating adult Dunlins (Calidris alpina): evaluating the effects of molting status and age. Ardea 81:9-20.

Iverson, G. C., S. E. Warnock, R. W. Butler, M. A. Bishop, and N. Warnock. 1996. Spring migration of Western Sandpipers along the pacific coast of North America: a telemetry study. Condor 98:10-21.

James, D. A., and J. C. Neal. 1986. Arkansas birds. University of Arkansas Press, Fayetteville, Arkansas, USA.

Kaiser, A. 1995. Estimating turnover, movements, and capture parameters of resting passerines in standardized capture-recapture studies. Journal of Applied Statistics 22:1039-1047.

Kaiser, A. 1999. Stopover strategies in birds: a review of methods for estimating stopover length. Bird Study 46:S299-S308.

Lehnen, S. E., and D. G. Krementz. 2005. Turnover rates of fall-migrating pectoral sandpipers through the Lower Mississippi Alluvial Valley. Journal of Wildlife Management 69:671-680.

Loesch, C. R., D. J. Twedt, K. Tripp, W. C. Hunter, and M. S. Woodrey. 2000. Development of management objectives for waterfowl and shorebirds in the Mississippi Alluvial Valley. Pages 8-11 in R. Bonney, D. N. Pashley, R. J. Cooper, and L. Niles, editors. Strategies for bird conservation: the partners in flight planning process, Proceedings of the 3rd Partners in Flight Workshop. Proceedings RMRS-P-16. U.S. Department of Agriculture, Forest Service, Rocky Mountain Research Station, Ogden, Utah, USA.

Lyons, J. E., and S. M. Haig. 1995. Fat content and stopover ecology of spring migrant Semipalmated Sandpipers in South Carolina. Condor 97:427-437.

Mitchell, D. W., and J. W. Grubaugh. 2005. Impacts of shorebirds on invertebrates in the Lower Mississippi Alluvial Valley. American Midland Naturalist 154:188-200.

Morris, S. R., D. A. Liebner, A. M. Larracuente, E. M. Escamilla, and H. D. Sheets. 2005. Multipleday constancy as an alternative to pooling for estimating mark-recapture stopover length in Nearctic-Neotropical migrant landbirds. Auk 122:319-328.

Myers, J. P., R. I. G. Morrison, P. Z. Antas, B. A. Harrington, T. E. Lovejoy, M. Sallaberry, S. E. Senner, and A. Tarak. 1987. Conservation strategy for migratory species. American Scientist 75:19-26. 
Pfister, C., M. J. Kasprzyk, and B. A. Harrington. 1998. Body-fat levels and annual return in migrating Semipalmated Sandpipers. Auk 115:904-915.

Pienkowski, M. W. and W. J. A. Dick. 1976. Some biases in cannon- and mist-netted samples of wader populations. Ringing and Migration 1:105-107.

Prater, A. J., J. H. Marchant, and J. Vuorinen. 1977. Guide to the identification and ageing of Holearctic waders. Maund and Irvine, Tring, UK.

Sandercock, B. K. 2006. Estimation of demographic parameters from live-encounter data: a summary review. Journal of Wildlife Management 70:1504-1520.

Skagen, S. K., and F. L. Knopf. 1994. Residency patterns of migrating sandpipers at a midcontinent stopover. Condor 96:949-958.

Skagen, S. K., and H. D. Oman. 1996. Dietary flexibility of shorebirds in the Western Hemisphere. Canadian Field Naturalist 110:419-432.

Thomas, B. T. 1987. Spring shorebird migration through central Venezuela. Wilson Bulletin 99:571-578.

Thompson, J. J. 1993. Modeling the local abundance of shorebirds staging on migration. Theoretical Population Biology 44:299-315.

Warnock, N., and M. A. Bishop. 1998. Spring stopover ecology of migrant Western Sandpipers. Condor 100:456-467.

Warnock, N., J. Y. Takekawa, and M. A. Bishop. 2004. Migration and stopover strategies of individual Dunlin along the Pacific coast of North America. Canadian. Journal of Zoology 82:1687-1697.

Weber, T. P., T. Alerstam, and A. Hendenströ. 1998. Stopover decisions under wind influence. Journal of Avian Biology 29:552-560.

White, G. C., and K. P. Burnham. 1999. Program MARK: survival estimation from populations of marked animals. Bird Study 46(Supplement):S120S138.

Ydenberg, R. C., R. W. Butler, D. B. Lank, B. D.
Smith, and J. Ireland. 2004. Western Sandpipers have altered migration tactics as Peregrine Falcon populations have recovered. Proceedings of the Royal Society of London: B 271:1263-1269. 